\title{
The Effect Of Total Quality Management On Organizational Performance: In Bahir Dar Textile Share Company
}

\author{
Abera Ayalew ${ }^{1 *}$, Gojjam Adem ${ }^{2}$ \\ 1. Management, College of Business and Economics, Werabe University. P. O Box 46 , Werabe, Ethiopia \\ 2. Management, College of Business and Economics, Debremarkos University, P.O Box 269, Debremarkos, Ethiopia \\ DOI: 10.29322/IJSRP.11.09.2021.p11738 \\ http://dx.doi.org/10.29322/IJSRP.11.09.2021.p11738
}

\begin{abstract}
This study investigates the effect of TQM and its dimension towards organizational performance in Bahir Dar Textile Share Company. The sample size of this study was 308 employees from 1385 total target population of Bahir Dar Textile Share Company. The researcher applied the explanatory research design and employed a quantitative data analysis method. The samples were selected randomly from the population after creating strata. Hence, stratified random sampling technique was employed. In this study, primary sources of data were used. The collected data was analyzed using descriptive statistics such as frequency tables, percentage, charts and inferential statistics such as correlations and regression analysis. The findings of this study indicated that there is a significant and moderately positive relationship between TQM dimension and organizational performance. Again the findings revealed that TQM dimension has a significant effect on organizational performance. The study concluded that the successful implementation of quality management practices to generate the desired performance and which should be planned, systematic and implemented by Bahir Dar Textile Share Company to this further result as organization productivity growth and performance. This study has forwarded as recommendations the government as well as the Share Company has to work more with the improvement of the current total quality management measures by taking into account the performance of the organization.
\end{abstract}

\section{Keywords}

Textile Share Company, TQM practice, organizational performance

\section{BACKGROUND OF THE STUDY}

Total Quality Management is the culture of an organization to commit to customer satisfaction through continuous improvement. This culture varies from one country to another country and between different industries, but has certain essential principles, which can be implemented to secure greater market share, increase profit and reduce costs (Kanji, 1997). This statement emphasizes that creating a quality culture within an organization is recognized as one of the primary condition for successful implementation of TQM.

The core values of TQM represent how to encourage and motivate employees to the best way to improve their capabilities, skilled, commitment and productive by giving them relevant information, power, knowledge, and rewards. So logically, the significant expected effect of the TQM principles will be on the firms overall business results. Besides most of the previous studies point out that productivity is one of the measure business performance directly affected by application of the TQM principles (Ahire et al.,1996).This means that the adoption of TQM concepts leads to inspiring employees to succeed and grow, then improving their performance and productivity (Okland, 1993).

In such a competitive environment resulted from world globalization and liberalization, firms survive with much difficulty unless they create the competitive advantage over their competitors (Samson and Terziovski, 1999). With the increasing competitive, business survival pressure and the dynamic, changing customer-oriented environment, total quality management (TQM) has been recognized as one of the important issues and generated a substantial amount of interest among managers and researchers (Ahire et al, 1996). 
Ethiopia has potential for the development of the industrial growth due to its natural resources bases. However, the industrial sector has not been adequately developed and its contribution to the national gross domestic product (GDP) and employment has been limited. According to National Account Statistics Estimate (2002), Ethiopian Fiscal year the industrial sector has $23 \%$ share of GDP and it grew by $20 \%$ in the year 2009/2010. The manufacturing sector has $43 \%$ share of Industrial sector and textile industry is one of the main Industries in this sector.

Since 2010 the Ethiopian government has put effort to improve, support and expand the textile industry, both in serving the domestic market but mainly with the aim to export and be competitive at the global market. Ethiopia has potential of building a textile industry with governmental support, offering low-cost production, raw material and with a growing young population eager for jobs. Ethiopia "e government is apparently placing special emphasis on the Textile industry by 2016; the country aims to export more than a billion dollars worth of apparel. Bahir Dar Textile Share Company is one of the industries which established in $1961 \mathrm{EC}$, produce garments and apparel for the local as well as the global market. In order to get competitive advantages in the market, it needs to put into practice incremental change like TQM, so as to increase performance and to hold up the country economy. Therefore, this study aims to investigate the effects of TQM implementation on organizational performance.

\subsection{Statement of the Problem}

In today ${ }^{e e}$ manufacturing companies compete by applying various competitive strategies and this competitive strategies will help them to win advantages over the competitors who are engaged in the industry. One of the strategies companies that use is improving the quality of the products that they are producing than that of the other companies. So as to do this, they must implement the TQM practices and procedures which are essential to improve quality of products as well.

Studies investigating the relationship between „harde and „softe ${ }^{\text {ee }}$ TQM factors and organizational productivity have revealed diverse results. This may be attributed to focus on different types of TQM practices as well as the use of different measures of organizational performance across the different studies. Prajogo and Sohal (2004), stated that different practices embodied in TQM show a different role in predicting different types of OP. Powell (1995) investigated the relationship between TQM practices and performance (as measured by "total performance" consisting of five items and "TQM performance" consisting of eight items). Their findings found that TQM can produce economic value to the company. In particular, the study found that practices, including Employee empowerment and executive commitment are highly correlated with TQM success than "hard" aspects of TQM such as process improvement, benchmarking, and improved measurement. However, another study conducted by (Samson and Terziovski, 1999) to determine the association between TQM practices, individually and collectively, and company performance in Australia showed that some, but not all, of the categories such as leadership, management of people, and customer focus were the strongest significant predictors of operational performance.

There are some contradictory findings in the literature, for instance, in contrast to the (Powell, 1995) findings, (Gadenne and Sharma, 2009) found that improved overall performance was favorably influenced by a combination of both hard and soft TQM practices. Demirbag and Koh (2006) investigated the impact of TQM implementation on OP of SMEs in textile manufacturing companies in Turkey; they reported a significant and positive impact of TQM implementation on non-financial Organizational Performance but a poor impact on financial performance.

According to Alkhafaji et al (1998), TQM philosophy can be applied to any organizations, including manufacturing, and beverage industries. Most of developing countries enterprises like brewery, textile, sugar, flour, and other Agro-processing industries are very low in their productivity as compared to other developing and developed nations as mentioned on there should be a change, representing nothing short of breakthrough for those organizations to halt productivity decline, such a change can be brought through management styles like TQM. However, the adoption of the ideology by most organization has been hampered due to their non compliance with the procedures and principles of TQM implementation. While some organization, run TQM like a program which they expect to function and perform the magic all by itself, others have used a half hearted approach to it, by using some bits and pieces of the principles. This has accounted for the failure of most organization in matting up to their expected target from implementing this ideology (Alkhafaji etal, 1998). There is a need to continue to buttress the benefit that accrues to organizations from the implementation of TQM, especially in developing economies, such as Ethiopia where the adoption of these principles seems farfetched by organizations.

The question of TQM and organizational performance has not exhaustively under investigation in Ethiopian context particularly in textile industry. Thus, this thesis proposes a framework to investigate the current status of TQM implementation and its effect on organizational performance in Bahir Dar Textile Share Company, accordingly making TQM initiatives more efficient and active in Ethiopian Textile Industry. 
The results of this study have significant effect for various aspects.

\section{Policy makers}

It will give important development and implementation of total quality management through reflecting the most difficulties observed in total quality management and provide appropriate ways of total quality management to minimize the effect of this management on organization performance especially, in Bahir Dar textile share company.

\section{For managers}

It helps to create awareness about the effects of TQM on organizational performance and assist to understand effects of TQM practices in managing human and other resource to achieve the common goal and objective in Bahir Dar textile share company and it will used as guideline to apply good TQM in this company .

\section{Academicians and researchers}

The result of this study will also use as a reference for the researcher successors who will study related research topic to the effect of TQM on organizational performance.

\subsection{Scope of the Study}

This study is also conceptually limited to the effect of total quality management on organizational performance. Even though wide range of variables may be expected to be studied; this study were contemplated on examination of total quality management and organizational performance, under TQM practices only the following variables are taken as the studying variables such as ; continuous improvement, customer focus, process management, supplier quality management, and top management commitment. Geographically, this study is also delimited only one textile manufacturing company of Bahir Dar Textile Share Company.

\section{Literature Review}

\subsection{Introduction}

In order to access the suitability of the various of TQM for the Ethiopian Textile Factory context, this chapter will provide a brief conceptual framework of Quality, TQM philosophy in terms of its definitions, development of TQM and its practices, critical success factors, obstacles and benefits. The chapter further provides information, empirical studies based on both Quality modes and other framework established in both developing and undeveloped countries. The final section of this chapter focuses on reviewing organizational performance associated with TQM implementation.

\subsection{Theoretical Literature}

\section{Nature of Quality}

Juran (1974) defined quality as fitness for use. The first part of the definition itself (use) is apparently linked to customers ${ }^{\text {ee }}$ needs, and the second part (fitness) suggests conformance to measurable product characteristics. This definition however implies an understanding $\mathrm{g}$ of the relationship between customer satisfaction and the conformance of product characteristics to product specifications (Juran and Gryna, 1988). In addition, Juran "es definition of Quality obviously includes two levels; level one (linking product characteristics and buyer's needs) and level two (linking quality with the absence of nonconformity) (Juran, and Gryna, 1988).

Crosby, (1979), defined quality as the conformance to requirements to specifications and also suggested that to manage quality adequately; it must be able to be measured.

\subsubsection{TQM definitions and the development of TQM}

Over time, Quality in manufacturing terms has developed from Inspection to TQM. Indeed, it is generally thought, that the Egyptians were the first to use Inspection as a test of Quality when building the pyramids. In the Second World War, when aircraft Technology became more complex, the inspection technique was impractical due to its cost in staff and equipment (Kanji, 2002). Inspection developed into quality control in which Quality manuals, document control, self inspection, product testing in addition to the use of statistics, become the control systems used to assure product quality. The subsequent stage was to move 
from the focus on product quality through quality circle $(\mathrm{QC})$, to Quality Assurance or $\mathrm{QM}$ where the focus on the quality of the system, which encompasses audits, process control, cost of poor quality and non- production operations are used (Kanji, 2002).

(Taguchi, 1999), stressed that companies should focus their quality efforts on product design stages, and called this ,robust design", because it is much cheaper and easier to make changes during the design process rather than during the production phase. Kanji and Yui (1997) developed a benchmarking toll for quality and argued that it is necessary for top managers to develop a „quality culture ${ }^{\text {ec }}$ within an organization by taking an active leadership role and involving all employees.

\subsubsection{Customer focus}

Organizations rely on their customers, so they must understand the current and future needs, and achieve their needs, and work to exceed their expectations. This is achieved through research and understand all the needs and expectations of the customer in terms of products, services and delivery date, price and reliability, and to link the goals established with the needs and expectations of the client, and follow the way of ensuring Alkhafaji et al. (1998) a balance between the needs and expectations of customers and other stakeholders (owners, employees, suppliers and the community), and inform all levels in the facility this needs and expectations, and measure customer satisfaction and act according to the results, customer relationship management to achieve the common interest.

\subsubsection{Top management commitment}

Total Quality philosophy derives its strength from the commitment of senior management in the application of total quality management in various organized activities. Leadership should play a key role in the establishment of a clear future vision of the facility, the development $\mathrm{t}$ of common values, justice and models of moral principles at all levels of the facility and maintain them, build trust and eliminate fear, and support personnel with the necessary resources and adequate training motivate employees and encourage the spirit of enthusiasm in them and appreciate the positive efforts, encouraging open communication, and improve awareness, education, training of workers, and exhibit their commitment to quality by example.

This element is considered as an important tool of TQM as it examines the senior Executives, leadership and personal involvement to provide direction for maintaining and building a system that enhances organizational performance. Leadership is liable for the Setting of goals that lead the organization towards increased performance. Deming (1986) provided that leadership is responsible to implement a quality Process in the organization.

\subsubsection{Process management}

Process management deals with how organization designs and introduces the product and services. It integrates production and delivery requirements that include relationship management with the suppliers (Brah and Tee, 2002). Deming (1986) said that improvement in the quality lies in the handling and controlling of the process. Many organizations found major improvement in the performance through the process redesigning and reengineering. Desired outcome achieved more effectively and efficiently when resources and activities are managed as a process-related. This is achieved by: identifying the activities needed to achieve the desired result, and measure the inputs and outputs of the process, and to identify the communication channels of main activities of the business, and the risk assessment results and the potential impacts of operations on customers, suppliers and other stakeholders, define clearly the responsibilities and authorities of the of the management of main activities. The focus should be on how best design, manage and improve processes in order to fully satisfy, and generate increasing value for, customers and other stakeholders (Al-Damen, 2017).

\subsubsection{Continuous improvement}

A major component of TQM is continual improvement. Continual improvement leads to improved and higher quality processes. The term continues refers to both incremental and breakthrough improvement. Continual improvement ensures companies find new ways and techniques in producing better quality products, production, be more competitive, as well as exceed customer expectations. Continues improvement is designed to ensure efficient and effective utilization of the resources of the organization and to achieve a quality driven culture (Al-Damen, 2017).

\subsubsection{Supplier Quality Management}


The success of TQM is vastly depending upon the organization's ability to satisfy and fulfill the interests of various stakeholders. Suppliers' ability to fulfill the needs of the organization, in terms of delivering quality input, is however also crucial for the organization. The importance of creating and sustaining superior supplier relationships is widely emphasized in empirical studies, as the quality of input, such as purchased raw materials, is directly related to the organizational product (Al-Damen, 2017).

\subsection{Definition of Organizational Performance}

Performance measurement tools can also be availed within the organizational framework. Activities around this area establishes the most important client needs, identifying specific quantifiable outputs and establishing targets against which results are to be scored. A variety of perspectives exists on the best approach to measure and quantify organizational performance depending on the dynamics of the industry.

Measuring profitability margins highlight the amount a given organization has invested in its operations. Raw growth revenue is important as it highlights the organizational expansion capacity and the scope of potential economies of scale. The market share of an organization can also be used to highlight its success relative to its immediate competition. In manufacturing organizations, brand loyalty can also be used to gauge the consumer loyalty and overall retention. It is only through performance that organizations are able to grow and progress (Crosby, 1979). In a manufacturing setting, knowing the determinants of organizational performance is the key in predicting the future, considering the numerous economic crises and shocks that have hit the economic landscape in the globe. The factors that are of most impact are isolated and then treated with utmost interest so as to ensure superior performance (Zabel and Avery, 2002). Further on, knowing the factors that generate success and how they can be measured is of critical importance.

\subsection{Conceptual Framework}

The independent variable is Total Quality Management. The indicators of total quality management are continuous improvement, customer focus, process improvement, supplier quality management, and top management commitment. The dependent variable is Organizational Performance.

Figure 2. 1 Conceptual Framework

\section{Total Quality Management}

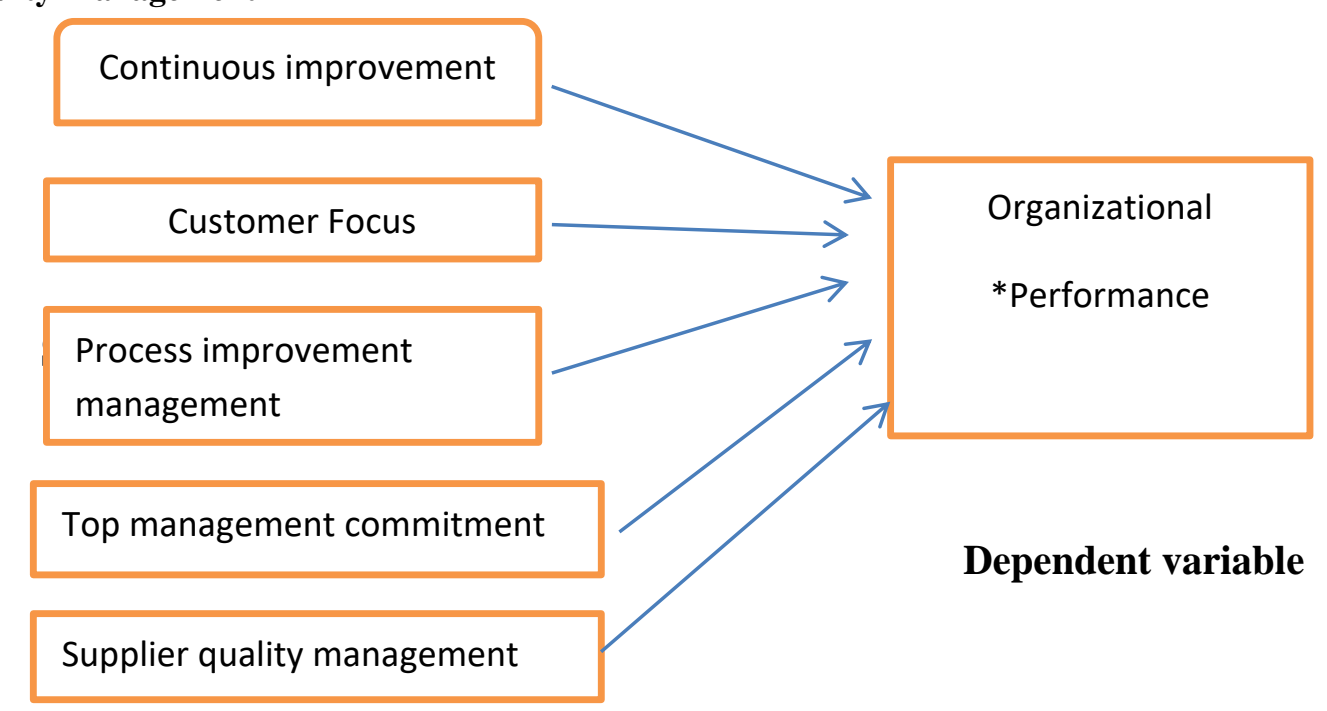

Independent variable

Source: (Jaafreh and Al-Abedalla, 2013; Al-Damen, 2017; Aysel etal., 2014; and Shafiq etal., 2017).

\subsection{Empirical Literature}

Total Quality Management is truly generic as it can be implemented in both manufacturing and services sectors and despite their different natures; they face similar problems in realizing the full benefits of TQM (Huq and Stolen, 1998). The implementation of quality program is gaining acceptance as a way of maintaining a competitive edge, of simply surviving in fiercely competitive 
market or increasing performance and productivity. From this perspective, product development or service development, and cost reduction is imperative (Al-khalifa and Aspinwall, 2000).

Small manufacturing companies that would face difficulties, in implementing TQM programs such as size related difficulties, the lack of bargaining power against suppliers, and lack of resources can focus on internal changes to improve quality, reduce inventory, and encourage employee participation and can, in general help to achieve competitive advantages in both domestic and international markets (Lee, 2004)

Das et al., (2006) found a positive association between TQM implementation and organizational performance and five of TQM principles, customer focus, continuous improvement; top management commitment, employee involvement, and product innovation have a significantly positive effect on product quality, recommending the use of reward and recognition for involving employees in TQM efforts. Salaheldin (2009) revealed that the implementation of TQM has a positive effect on both the operational and the organizational performance. The results show that customer focus, continuous improvement, top management commitment, employee involvement and product innovation are significantly and positively related to product quality.

Sadikoglu et al. (2014) found that different TQM practices significantly affect different performance outcomes. Abuzaid (2015) indicated that the Jordanian private hospitals applying the total quality management practices with high degree. The highest focus of private hospitals within total quality management practices is on customer orientation, supplier management, and high support from top management to the quality efforts and a concern from the target hospitals in participation of employees in quality management activities. Most empirical studies seem to agree with those of Powell (1995), Hendricks and Singhal (1997) that TQM practices has a positive impact on organizational performance. In Powellees study (1995), data from 166 American firms were used to show that overall performance of TQM correlated positively and significantly with both implementing TQM and its degree of advancement or organizational performance. Although the empirical literature suggests a positive link between TQM and organizational performance, the level of contribution attributed to TQM was not large, suggesting that there could be other variables at play. Those variables could be the differences in the processes of implementing TQM with respect to economic trends, the type of industry, the business environment including technology, competitiveness and market, corporate strategy, resources of firm, etc. Prajogo and Brown (2004) conducted an empirical study on Australian organizations to investigate the relationship between TQM practices and quality performance. The results indicated a strong and positive linkage between those two variables. Brah and Tee , (2002) examined the relationship between TQM constructs and organization performance by measuring the quality performance of Singapore companies. They found that TQM and performance were positively correlated.

Another wave of research has focused on the study between TQM and financial performance; Fotopoulos et al (2009) studies show that firms that focus on improving the quality of their product and processes improve revenues and reduce costs. So the financial performance of a firm as a result of quality initiatives can be measured by the increase in the level of sales and revenues, the level of cost reduction, the return on investment, and by the increase in market share.

Hendricks and Singhal (1997) compare recipients of quality awards with a group of "control companies". Using operating income, sales, return on assets, return on sales as a measure of performance, they found that companies that had received a quality award outperform those that did not receive the awards. These results were confirmed by Easton and Jarrell (1998) studies.

\section{Research Gaps}

A lot of studies were conducted related to TQM on organizational performance in different countries but it has not exhaustively under investigation in Ethiopian context particularly in textile industry. Thus, this thesis proposes a framework to investigate the current status of TQM implementation and its effect on organizational performance in Bahir Dar Textile Share Company, accordingly making TQM initiatives more efficient and active in Ethiopian Textile Industry.

\section{Summary}

The independent variables were; continuous improvement, customer focus, process management, supplier quality management, and top management commitment. The dependent variable was organizational performance in Bahir Dar Textile Share Company in Bahirdar city, Ethiopia

\section{Research Methodology}

\subsection{Research Design}


For this study the researcher was apply the explanatory type of design to analyze the data. According to Saunders et al (2007), explanatory research design is that establish causal relationship between variables may be termed explanatory studies here is on studying the problem in order to explain the effect of TQM on organizational performance. It enables the researcher to analyze the effect of independent variables (TQM practices) on dependent variable (Organizational Performance).

\subsection{Research approach}

To generate necessary information and come up with more rich and comprehensive data, the researcher was employed quantitative research approach for this study.

\subsection{Target Population of the Study}

There are 1495 total employees in Bahir Dar Textile Share Company. For the purpose of this study, the researcher identified the entire permanent employees of 1385 workers. From this 502 are females and 883 males.

Table 3. 1 summary of target population

\begin{tabular}{|l|l|}
\hline Departments & $\begin{array}{l}\text { Total number Of } \\
\text { target population }\end{array}$ \\
\hline HRM & 84 \\
Selling & 15 \\
\hline Production and & 1125 \\
\hline Purchasing and & 13 \\
\hline Quality & 17 \\
\hline Total & $\mathbf{1 2 5 4}$ \\
\hline
\end{tabular}

Source: BDTSC human resource department (2018)

\subsection{Sample Size and Sampling Technique}

According to data from human resource department of BDTSC, there are 1385 employees as of 2017 budget year that make up the sampling frame. The sampling frame for any probability sample is a complete list of all the cases in the population from which the sample was draw. Then the researcher was determined the sample size based on the formula of Yamane, (1967) which is a simplified formula for calculating the sample size for not very large enough and known population size. The formula is as follows;

$$
n=\frac{N}{1+N(e) 2}
$$

Where, $\mathrm{n}$ is the sample size, $\mathrm{N}$ is the total target population which is 1385 , and $\mathrm{e}$ is the error or confidence level, the conventional confidence level of $95 \%$ would be used to ensure a more accurate result from the sample. Based on this, the error term would equal to 0.05. Using the total Population of 1385and error margin of 0.05, the sample size was calculated. Hence, out of the total population 1385, a total sample size of 308 numbers of respondents is taken.

$$
\begin{aligned}
& 1385 \\
= & 1+1385(0.05)^{2} \quad,=308
\end{aligned}
$$


The following table summarizes the total target population in each department of respondents" and the corresponding Sample size would be taken from each stratum as follows. 
Table 3. 1 Sample size determination

\begin{tabular}{|l|l|l|l|}
\hline Departments & $\begin{array}{l}\text { Total number of } \\
\text { target population }\end{array}$ & $\begin{array}{l}\text { Proportion for } \\
\text { each category }\end{array}$ & Sample size \\
\hline HRM & 84 & $84 / 1254 \times 308$ & 21 \\
\hline Selling & 15 & $15 / 1254 \times 308$ & 4 \\
\hline Production and & 1125 & $1125 / 1254 \times 308$ & 276 \\
\hline Purchasing and & 13 & $13 / 1254 \times 308$ & 3 \\
Store & & & \\
\hline Quality & 17 & $17 / 1254 \times 308$ & 4 \\
\hline Total & $\mathbf{1 2 5 4}$ & & $\mathbf{3 0 8}$ \\
\hline
\end{tabular}

Source: BDTSC human resource department (2018)

\subsection{Sampling technique}

The researcher was used stratified random sampling for this study appropriate for selecting samples from the population. Stratified random sampling allows us to take into account the different subgroups of people in the population (such as different divisions \& departments) and helps guarantee that the sample accurately represents the population on specific characteristics. The researcher started by dividing the population into sub departments or strata and in this study cases the criteria of strata identification is departmental units. Then sample is randomly selected from each stratum or department units. Therefore, the population can be divided into five sub groups such as; human resource management, marketing, production, and purchasing and store departments. These groups can be considered as stratum. Finally lottery random sampling was employed. Then the researcher selects samples from each stratum as follows: The number of samples is determined proportionally by considering the number of employees in each departments of the Bahir Dar Textle Share Company.

\subsection{Data Source and Type}

The source of the data was entirely from primary sources. Primary data was collected by use of structured questionnaires across the strata.

\subsection{Data Collection Method}

The survey was conducted directly to respond workers that exist in the BDTSC targeting the respondents at stratified random sampling method from the population of the whole Bahir Dar Textile Share Company employees. Self-administered questionnaires which consists closed ended questions were used. Questionnaires are considered the best in collection of primary data because they provide an avenue for the researchers to ask probing questions, they are fast, cheap and can be self administered (Mugenda \& Mugenda, 2003). The instrument that it is employed in this research is a questionnaire adapted from (Shafiq etal 2017; Al-Damen, 2017; Aysel et al.2014; Jaafreh and Al-abedallat 2013) who measured the scale in different studies. The questionnaires would be rated on the five points Likert scale ranged from strongly disagrees, allocate a scale of 1 , to strongly agree, allocate a scale of 5 . 


\subsection{Method of Data Analysis}

In this study data collection from survey questionnaire was interred into SPSS (statistical package for social science) software, version 20 for analysis.

Both descriptive statistic and inferential analysis were used to analyze the data. Descriptive statistics allows researcher to present the data queried in structured, accurate, and summarized manner (Collis \& Roger, 2003). The descriptive statistics (frequency, percentage, mean and standard deviation) utilized in this study were used to analyze the demographic data and for the descriptive analysis of the variables. Inferential analysis is concerned with the Pearson correlation and multiple regression analysis was performed. Multiple regression analysis was used to determine the relationship between the independent variables (continuous improvement, customer focus, process management, supplier quality management, and top management commitment) and the dependent variable (organizational performance).

\subsection{Methods of data presentation}

After collecting the data, the researcher presented quantitative data through tabular and graphic methods of presentation, frequency and percentage. Qualitative data was presented descriptively.

\section{Finding and discussion}

\subsection{Introduction}

This chapter explains the information gathered from the survey through the use of questionnaires. The responses of respondents have been analyzed and results have been presented in the form of chart, tables and figures. In this chapter, the first part of the study, which is devoted to the demographic characteristics of respondents, is dealt with. The second part is linked with the analysis of collected data that carried out in relation to the objectives of the study. This includes the TQM implementation and its effect on organizational performance in Bahir Dar Textile Share Company.

\section{Reliability and Validity of the Instrument}

The reliability of the questionnaire was evaluated through Cronbach "es Alpha which measures the internal consistency. The Alpha

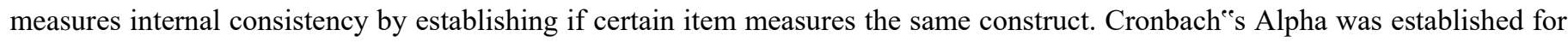
every objective in order to determine if each scale (objective) would produce consistent results should the research be done later on. The findings of the pilot study shows that all the four scales were reliable as their reliability values exceeded the prescribed threshold of 0.7 (Mugenda and Mugenda, 2003).

Validity is the most critical criterion and indicates the degree to which an instrument measures what it is supposed to measure (Kothari, 2004).In order to ensure the validness of this study the instruments were checked and evaluated by professionals in the subject matter area. Moreover my advisor had evaluated and commented on the instruments before they are distributed to the respondents 
Table 3. 2 Reliability test of variables by Cronbach's Alpha

\begin{tabular}{|l|l|l|}
\hline Variables & No of items & Cronbach's Alpha \\
\hline Continuous Improvement & 5 & 723 \\
\hline Customer Focus & 5 & 747 \\
\hline Process Management & 4 & .728 \\
\hline Supplier Quality Management & 5 & .702 \\
\hline Top Management Commitment & 6 & 721 \\
\hline Organizational Performance & 11 & 720 \\
\hline
\end{tabular}

Source: Own Survey, 2018

As its shown from the table 3.2 the reliability test cronbach alpha of all variable indicates above 0.7 which indicates all domains of variables reliable and it measuring what its suppose to measure.

\section{Demographic Characteristics of the Respondents}

The survey on demographic characteristics of the respondents constituted of gender, age distributions, educational level, work experience and current job position of respondents.

\section{Figure4. 1 Gender of respondents}

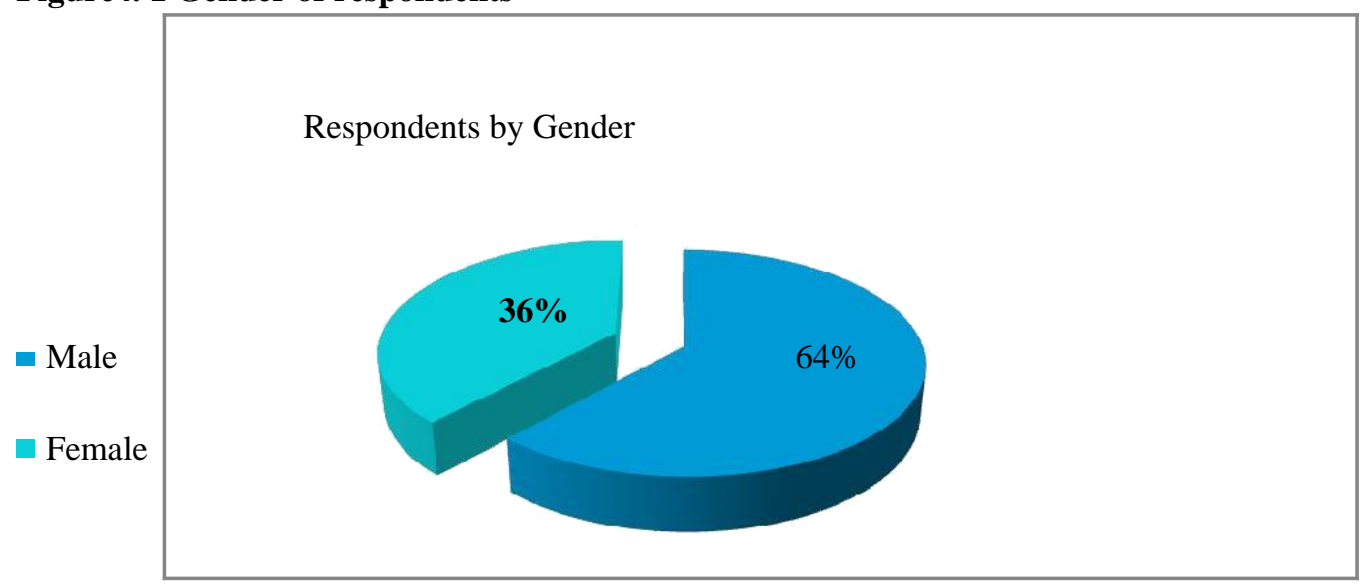

\section{Source: Own Survey, 2018.}

According to the figure 4.1 above, 198 (64.3\%) of respondents were Males whilst 110(35.7\%) were Females. The fact that the majority of the respondents are Males, as per the researcher"s observation, strongly confirms that has more male staff than female in Bahirdar textile Share Company. 
Figure 4. 2 Age of respondents

Distribution of respondants by Age

124

95

60

29

18-30

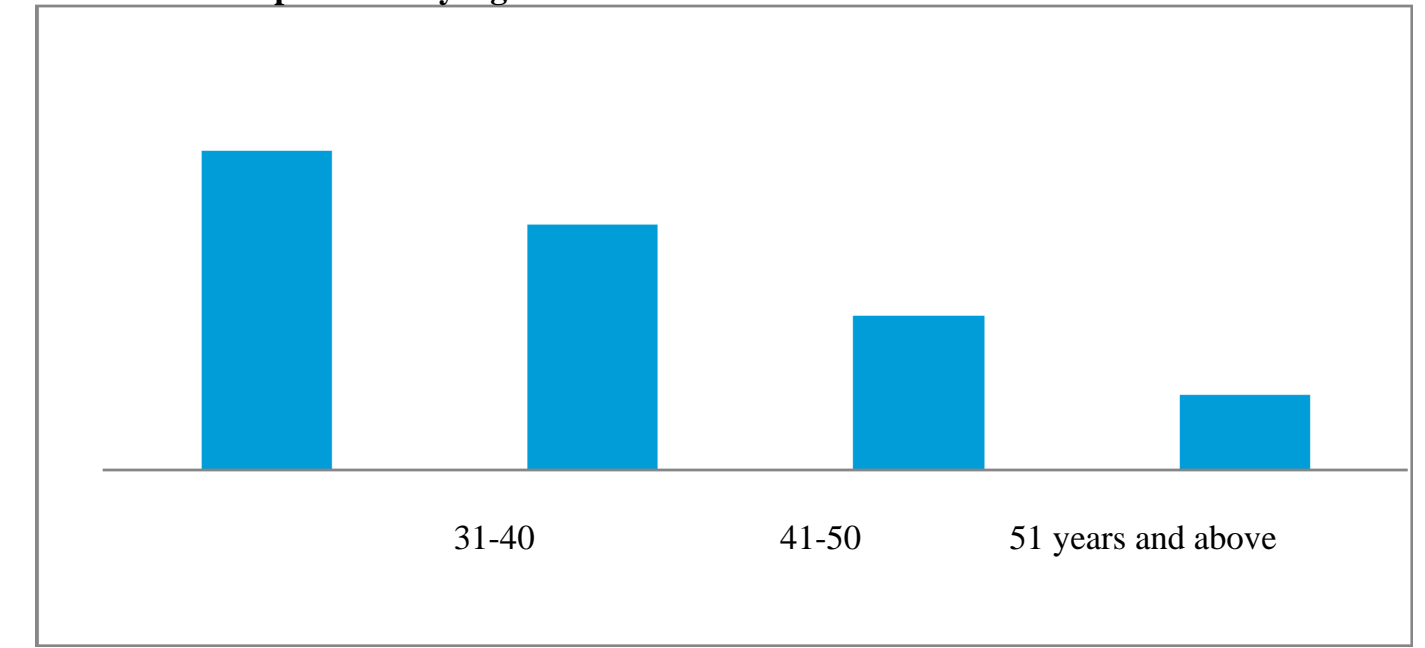

\section{Source: Own Survey, 2018}

The frequencies from figure 4.2 showed that 124 (40.3\%) of respondents who participated in the survey were between the age range of 18 to 30 years, followed by the range of 31 to 40 years comprising 95 respondents (30.8\%), 60 (19.5\%) constituting an age from 41 to 50 years old whereas, the remaining 29 (9.4\%) were the respondents between 51 years and above. The data shows that the majority of the respondents were at productive ages i.e. age range from 18 to 39 years or constitute $71.1 \%$. Accordingly, such employees who are in the age range above need to be treated because it is productive age for the company.

\section{Figure 4. 3 Level of Education}

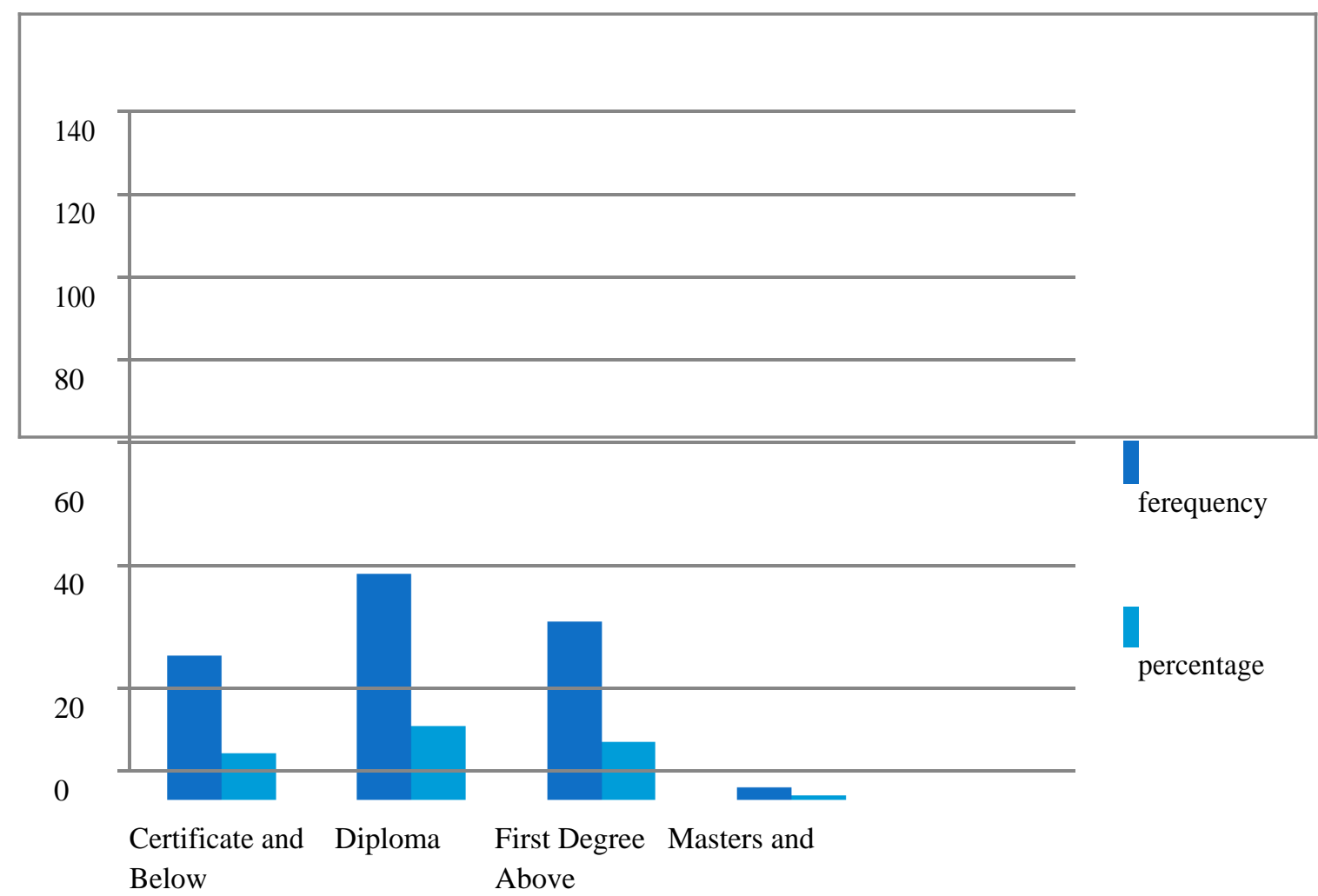

\section{Source: Own Survey, 2018.}

It is revealed from the bar chart that $124(40.3 \%)$ are diploma holders followed by $98(31.8 \%)$ first degree, $79(25.6 \%)$ certificate and below, $7(2.3 \%)$ of masters and above. The research shows that greater percentage of workers in Share Company is well educated that is diploma and above holders this implies it is good understanding in order to perform their own tasks. 
Table 4. 1 Work Experience

\begin{tabular}{|c|c|c|c|}
\hline \multicolumn{4}{|c|}{ Years of service in the company } \\
\hline & & Frequency & Percentage \\
\hline \multirow{6}{*}{ Valid } & $1-5$ years & 57 & 18.5 \\
\hline & $5-10$ years & 43 & 14.0 \\
\hline & $10-15$ years & 48 & 15.6 \\
\hline & $15-20$ years & 111 & 36.0 \\
\hline & Above 20 years & 49 & 15.9 \\
\hline & Total & 308 & 100.0 \\
\hline
\end{tabular}

\section{Source: Own Survey, 2018.}

On the other hand, from the above table 111 (36\%) respondents ${ }^{\text {ee }}$ have worked in the company for 15-20 years followed by 57 (18.5\%) for $1-5$ years, $49(15.9 \%)$ above 20 years, $48(15.6 \%)$ for 10-12 years and 43 (14\%) for 5-10 years. From this the researcher found the majority of the employees do work beyond 10 years or more. This implies the share company employees have experienced which results well informed the rule and regulation of the company also knows the trend of total quality management in the company.

\section{Table 4. 2 Job Position}

\begin{tabular}{|l|l|l|l|}
\hline \multicolumn{3}{|l|}{ Distribution of Respondents by job position. } \\
\hline \multirow{3}{*}{ Valid } & Frequency & Percentage (\%) \\
\cline { 2 - 4 } & Manager & 44 & 14.3 \\
\cline { 2 - 4 } & Non managerial & 264 & 85.7 \\
\cline { 2 - 4 } & Total & 308 & 100.0 \\
\hline
\end{tabular}

\section{Source: Own Survey, 2018.}

As per the table above, out of the total sample size of Three Hundred Eight (308), 264 (85.7\%) were selected from non managerial position, and the rest $44(14.3 \%)$ would be selected from managerial position. This shows that most employees engaged in the share company is at non managerial level.

Table 4. 3 Continuous Improvements

\begin{tabular}{|c|c|c|c|}
\hline Questions & Valid & Frequency & Percent \\
\hline The organization encourages & Strongly Disagree & 110 & 35.7 \\
\hline continual survey and improvement of & Disagree & 95 & 30.8 \\
\hline all its products, services and & Neutral & 40 & 13.0 \\
\hline \multirow[t]{3}{*}{ processes. } & Agree & 58 & 18.8 \\
\hline & Strongly Agree & 5 & 1.6 \\
\hline & Total & 308 & 100.0 \\
\hline
\end{tabular}




\begin{tabular}{|c|c|c|c|}
\hline \multirow{2}{*}{$\begin{array}{l}\text { I have got continuous training to } \\
\text { enhance internal quality of }\end{array}$} & \multirow{2}{*}{\begin{tabular}{|l} 
Strongly Disagree \\
Disagree
\end{tabular}} & \multirow{2}{*}{$\begin{array}{l}\beta 0 \\
113\end{array}$} & \multirow{2}{*}{$\frac{9.7}{36.7}$} \\
\hline & & & \\
\hline \multirow[t]{4}{*}{ performance. } & Neutral & 97 & 31.5 \\
\hline & Agree & 65 & 21.1 \\
\hline & Strongly Agree & 3 & 1.0 \\
\hline & Total & 308 & 100.0 \\
\hline \multirow{6}{*}{$\begin{array}{l}\text { There is frequently measure the } \\
\text { product and process quality. }\end{array}$} & Strongly Disagree & 111 & 36.0 \\
\hline & Disagree & 70 & 22.7 \\
\hline & Neutral & 73 & 23.7 \\
\hline & Agree & 47 & 15.3 \\
\hline & Strongly Agree & 7 & 2.3 \\
\hline & Total & 308 & 100.0 \\
\hline The company uses Plan Do Check & Strongly Disagree & 176 & 57.1 \\
\hline Act cycle (PDCA) extensively for & Disagree & 94 & 30.5 \\
\hline \multirow[t]{4}{*}{ process control and improvement } & Neutral & 14 & 4.5 \\
\hline & Agree & 18 & 5.8 \\
\hline & Strongly Agree & 6 & 1.9 \\
\hline & Total & 308 & 100.0 \\
\hline The decisions regarding quality & Strongly Disagree & 131 & 42.5 \\
\hline improvement always are based on & Disagree & 106 & 34.4 \\
\hline \multirow[t]{4}{*}{ objective data. } & Neutral & 43 & 14.0 \\
\hline & Agree & 22 & 7.1 \\
\hline & Strongly Agree & 6 & 1.9 \\
\hline & Total & 308 & 100.0 \\
\hline
\end{tabular}

Source: Own Survey, 2018. 
Table 4.3 above shows, It is clearly stated that $113(36.7 \%)$ have strongly disagreed with the organization encourages continual survey and improvement of all its products, services and processes. The other $95(30.8 \%)$ of the respondents have also disagreed with the question raised. But, $58(18.8 \%)$ of respondents have agreed with the organization encourages continual survey and improvement of all its products, services and processes. $40(13 \%)$ of respondents have come to be indifferent or are not quite sure to share their views. The remaining $5(1.6 \%)$ of the respondents have also strongly Agree. From the above respondents response majority or $205(66.6 \%)$ of them are against or disagree and above the question the organization encourages continual survey and improvement of all its products, services and processes.

The second item of the above table the respondents stated that $137(37.5 \%)$ of them are disagreeing, $97(31.7 \%)$ neither agrees nor disagree, $65(21.1 \%)$ respondents ${ }^{\text {ee }}$ answers agree, 30 (9.7\%) strongly disagree and $3(1 \%)$ strongly agree with getting continuous training to enhance internal quality of performance. From the above result majority or $143(46.7 \%)$ respondent answer the question disagree and above with getting continuous training to enhance internal quality of performance. This response shows that there is no getting continuous training to enhance internal quality of performance.

The third item of the above table the respondents stated that $111(36 \%)$ of them are strongly disagreeing, 73(23.7\%) neither agrees nor disagree, $70(22.7 \%)$ respondents ${ }^{\text {ee }}$ answers disagree, $47(15.3 \%)$ agree and $7(2.3 \%)$ strongly agree with there is frequently measure the product and process quality. From the above result majority or $181(58.8 \%)$ respondent answer the question disagrees and above with there is frequently measure the product and process quality. This response shows that there is no frequently measure the product and process quality.

The forth item of the above table the respondents stated that $176(57.1 \%)$ of them are strongly disagreeing, $94(30.5 \%)$ respondentse answers disagree, 18 (5.8\%) agree, 14 (4.5\%) neither agrees nor disagree, and 6 (1.9\%) strongly agree with the company uses Plan Do Check Act cycle (PDCA) extensively for process control and improvement. From the above result majority or $270(87.7 \%)$ respondent answer the question disagrees and above with The Company uses Plan Do Check Act cycle (PDCA) extensively for process control and improvement. This response shows that the company does not uses Plan Do Check Act cycle (PDCA) extensively for process control and improvement.

The study indicated whether there is the decisions regarding quality improvement always are based on objective data. Therefore, among the total respondents as shown in table 4.3 above, majority that representing $41.5 \%$ strongly disagreed with the idea. Likewise, $34.4 \%$ respondents also disagree on this issue. The next largest respondents were neutral which represents $14 \%$ and followed by $7.1 \%$ agree respondents and the rest $1.9 \%$ that strongly agreed on the decisions regarding quality improvement always are based on objective data. From this we can understand that in Bahir Dar Textile Share Company there is no always quality improvement based on objective data.

\section{Table 4. 4 Customer focus}

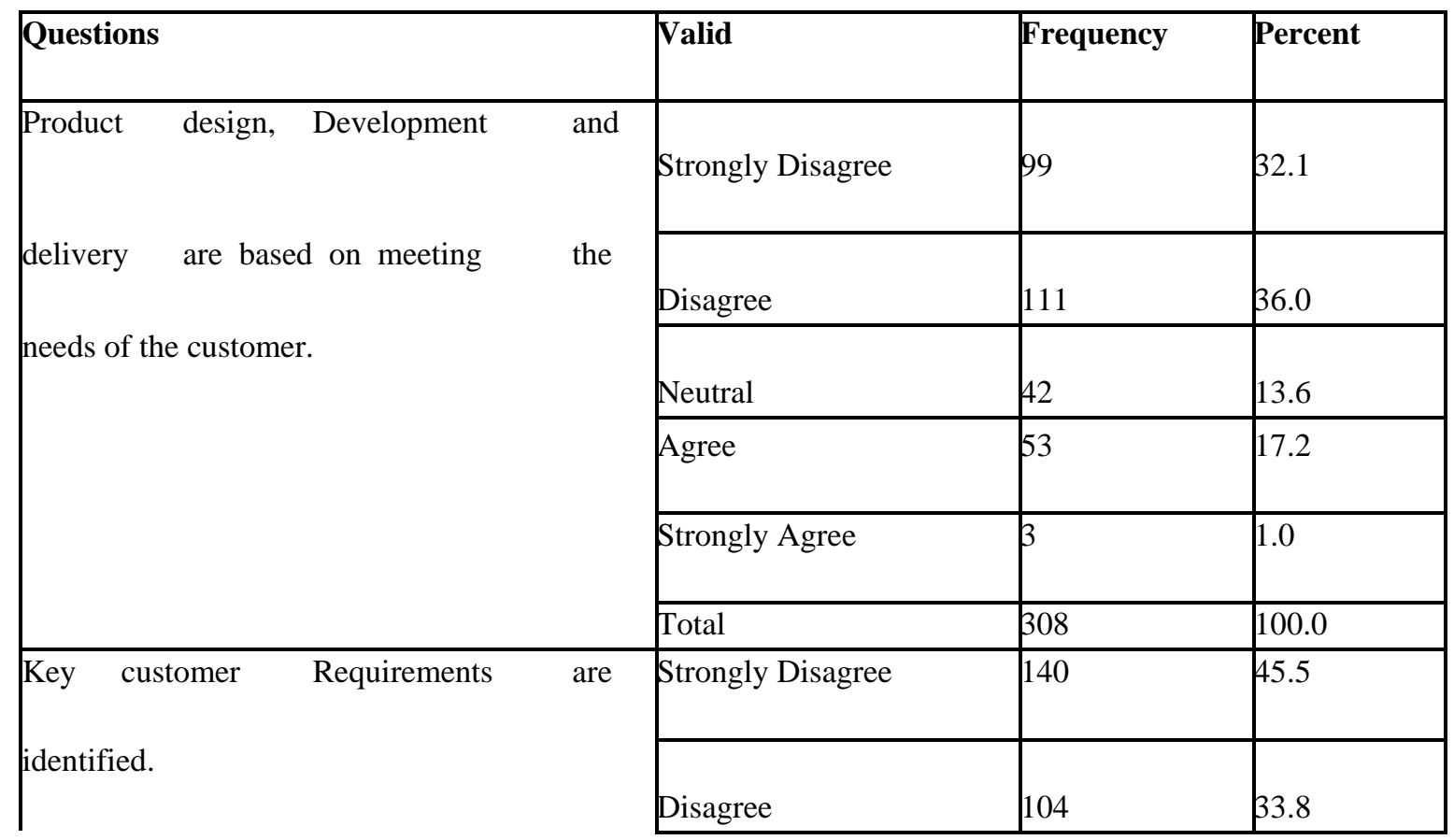




\begin{tabular}{|c|c|c|c|}
\hline & Neutral & 45 & 14.6 \\
\hline & Agree & 17 & 5.5 \\
\hline & Strongly Agree & 2 & .6 \\
\hline & Total & 308 & 100.0 \\
\hline \multirow{6}{*}{$\begin{array}{l}\text { There is a measure of customer } \\
\text { satisfaction on a regular base. }\end{array}$} & Strongly Disagree & 167 & 54.2 \\
\hline & Disagree & 100 & 32.5 \\
\hline & Neutral & 33 & 10.7 \\
\hline & Agree & 6 & 1.9 \\
\hline & Strongly Agree & 2 & .6 \\
\hline & Total & 308 & 100.0 \\
\hline \multirow{6}{*}{$\begin{array}{l}\text { The Company conducts customer } \\
\text { feedback surveys regularly }\end{array}$} & Strongly Disagree & 122 & 39.6 \\
\hline & Disagree & 89 & 28.9 \\
\hline & Neutral & 40 & 13.0 \\
\hline & Agree & 49 & 15.9 \\
\hline & Strongly Agree & 8 & 2.6 \\
\hline & Total & 308 & 100.0 \\
\hline \multirow{4}{*}{$\begin{array}{l}\text { Customer-focused strategies and } \\
\text { approaches are continuously reviewed } \\
\text { for further improvement. }\end{array}$} & Neutral & 9 & 2.9 \\
\hline & Agree & 163 & 52.9 \\
\hline & Strongly Agree & 136 & 44.2 \\
\hline & Total & 308 & 100.0 \\
\hline
\end{tabular}

\section{Source: Own Survey, 2018.}

Table 4.4 above shows, it is clearly stated that $111(36 \%)$ have disagreed with Product design; development and delivery are based on meeting the needs of the customer. The other 99 (32.1\%) of the respondents have also strongly disagreed with the question raised. But, $53(17.2 \%)$ of respondents have agreed with the Product design, development and delivery are based on meeting the needs of the customer. $42(13.6 \%)$ of respondents have come to be indifferent or are not quite sure to share their views. The remaining 3 (1\%) of the respondents have also strongly Agree. From the above respondents response majority or 200 $(68.2 \%)$ of them are against or disagree and above the question Product design, development and delivery are based on meeting the needs of the customer.

The second item of the above table the respondents stated that $45.5 \%$ of them are strongly disagreeing, $33.8 \%$ disagree, $14.6 \%$ neither agrees nor disagree, $5.5 \%$ respondents" answers agree, $0.6 \%$ strongly agree with Key customer requirements are identified. From the above result majority or $79.2 \%$ respondent answer the question disagree and above with Key customer requirements are identified. This response shows that there is no identified key customer requirement.

The third item of the above table the respondents stated that 167 (54.2\%) of them are strongly disagreeing, $100(32.5 \%)$ respondents" answers disagree, $33(10.7 \%)$ neither agrees nor disagree, $6(1.9 \%)$ agree and $2(0.6 \%)$ strongly agree with there is a measure of customer satisfaction on a regular base. From the above result majority or $86.7 \%$ respondent answer the question 
disagrees and above with there is a measure of customer satisfaction on a regular base. This response shows that there is no a measure of customer satisfaction on a regular base.

From the above table 4.4 the respondents stated that $122\left(39.6 \%\right.$ 0of them are strongly disagreeing, $89 / 29.8 \%$ respondents ${ }^{\text {ee }}$ answers disagree, $49(15.9 \%)$ agree, $40(13 \%)$ neither agrees nor disagrees, and $8(2.6 \%)$ strongly agree with the question the Company conducts customer feedback surveys regularly. From this result majority or $210(68.5 \%)$ respondent answer the question disagree and above with the Company conducts customer feedback surveys regularly.

The study indicated whether there is a Customer-focused strategy and approaches are continuously reviewed for further improvement in the company. Therefore, among the total respondents as shown in table 4.4, majority that representing $52.9 \%$ agreed with the idea. Likewise, $42.2 \%$ respondents also strongly agree on this issue. The rest $2.9 \%$ that neutral on Customerfocused strategy and approaches are continuously reviewed for further improvement in the company. From this we can understand that there is continuously reviewed customer focus strategy and approach for further improvements in company.

\section{Table 4. 5 Process Management}

\begin{tabular}{|c|c|c|c|}
\hline Questions & Valid & Frequency & Percent \\
\hline Production equipment is maintained & Strongly Disagree & 74 & 24.0 \\
\hline \multirow[t]{5}{*}{ well according to maintenance plan. } & Disagree & 92 & 29.9 \\
\hline & Neutral & 75 & 24.4 \\
\hline & Agree & 66 & 21.4 \\
\hline & Strongly Agree & 1 & 3 \\
\hline & Total & 308 & 100.0 \\
\hline We have site wide standardized and & Strongly Disagree & 11 & 3.6 \\
\hline \multirow[t]{5}{*}{ documented operating procedures. } & Disagree & 150 & 48.7 \\
\hline & Neutral & 80 & 26.0 \\
\hline & Agree & 64 & 20.8 \\
\hline & Strongly Agree & $\beta$ & 1.0 \\
\hline & Total & 308 & 100.0 \\
\hline The company systematically & Strongly Disagree & 85 & 27.6 \\
\hline \multirow{3}{*}{ 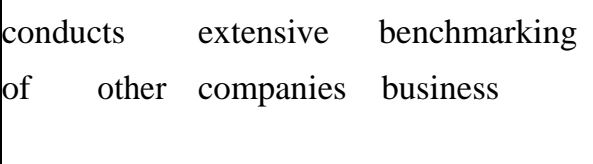 } & Disagree & 90 & 29.2 \\
\hline & Neutral & 77 & 25.0 \\
\hline & Agree & 55 & 17.9 \\
\hline \multirow{2}{*}{ process. } & Strongly Agree & 1 & 3 \\
\hline & Total & 308 & 100.0 \\
\hline Production processes are capable of & Strongly Disagree & 59 & 19.2 \\
\hline $\begin{array}{l}\text { producing products according to } \\
\text { design specifications }\end{array}$ & Disagree & 108 & 35.1 \\
\hline
\end{tabular}




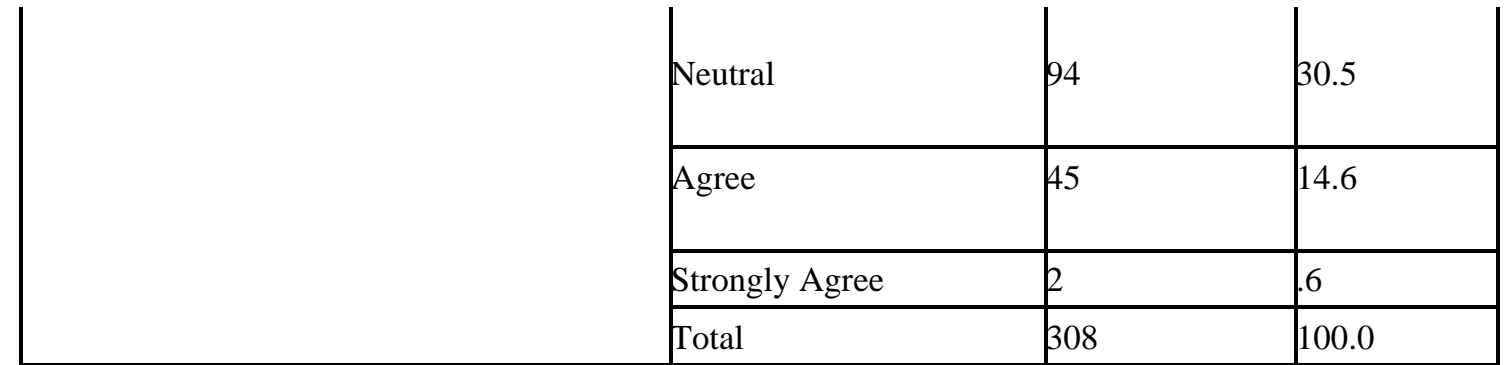

Source: Own Survey, 2018.

Table 4.5 above revealed that, majority of respondents representing $29.9 \%$ disagreed; followed $24.4 \%$ neutral on Production equipment is maintained well according to maintenance plan. In other case, $24 \%$ strongly disagree and $21.4 \%$ agree respectively. In addition to this, $0.3 \%$ of respondents strongly agreed on Production equipment is maintained well according to maintenance plan. Here, in the company there is no majority of Production equipment is maintained well according to maintenance plan.

The other point was about the site wide standardized and documented operating procedures. From the above table 4.5 the respondents stated that $150(48.7 \%)$ of them are disagreeing, $80(26 \%)$ neither Agree nor disagree. On the other hand $64(20.8 \%)$ agree, $11(3.6 \%)$ strongly disagree and $3(1 \%)$ strongly agrees with the question. From 36 this result majority or $52.3 \%$ respondent answer the question disagree and above with the site wide standardized and documented operating procedures.

The other point was about the company systematically conducts extensive benchmarking of other companies business process. Hence, as shown in table 4.5 above, $29.2 \%$ disagreed, $27.6 \%$ strongly disagree with the company systematically conducts extensive benchmarking of other companies business process. In the same table above, $25 \%$ neutral, $17.9 \%$ agree and $0.3 \%$ strongly agrees systematically conducts extensive benchmarking of other companies business process respectively. From this result majority or $56.8 \%$ respondent answers the questions disagree and above with the systematically conducts extensive benchmarking of other companies business process.

In addition, respondents were asked to the Production processes are capable of producing products according to design specifications. Hence, in as indicated in table 4.5 majorities of the respondents that representing $35.1 \%$, 30.5\% and $19.2 \%$ disagreed, neutral and strongly disagree respectively. On the other hand $14.6 \%$ respondents agreed and $0.6 \%$ strongly agrees with the capability of Production processes on producing products according to design specifications. So the majority of the respondent do not satisfied with the capability of Production processes on producing products according to design specifications of the organization. 
Table 4. 6 Suppliers Quality Management

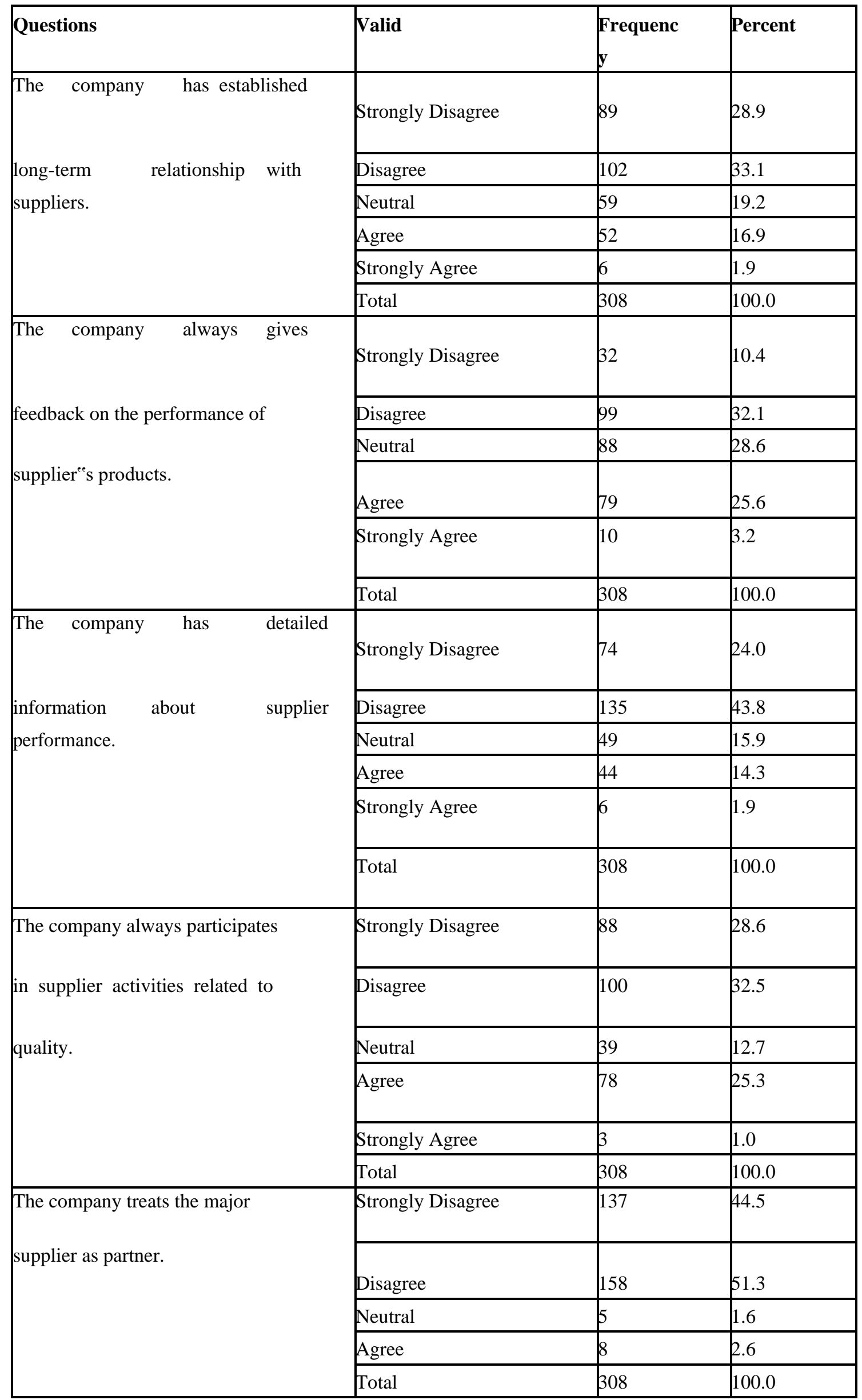




\section{Source: Own Survey, 2018.}

The field survey shows that $62 \%$ of the respondents disagrees and above with The Company has established long-term relationship with suppliers but only $19 \%$ of the respondents agree with the statement that they The company has established longterm relationship with suppliers $19 \%$ been neutral as shown in table 4.6 above.

When respondents were asked about whether the company always gives feedback on the performance of supplieres products. Table 4.6 shows that $42 \%$ of respondents 38 representing disagree with the company always gives feedback on the performance of supplieres products, $29 \%$ of them are agree with The company always gives feedback on the performance of supplier $\mathrm{se}$ products whilst $29 \%$ are uncertain.

The respondents were asked to indicate the Company has detailed information about supplier performance. From table 4.6, it can be noted that $68 \%$ of the respondents does not believes that Company has detailed information about supplier performance. $26 \%$ of them are agree with the Company has detailed information about supplier performance whilst $16 \%$ are uncertain. Going with the majority, it can be concluded that the Company has not detailed information about supplier performance.

From the field survey, the results shows that $61 \%$ majority of the respondents believes that there is the company does not always participates in supplier activities related to quality and $26 \%$ of the respondents believes that company has always participates in supplier activities related to quality but $13 \%$ neither agree nor disagree as shown in table 4.6. This implies that company does not always participate in supplier activities related to quality.

In addition Table 4.6 above shows that $96 \%$ of the respondents in the company disagree with the company treats the major supplier as partner. Only $3 \%$ agree with the statement and $2 \%$ uncertain with The Company treats the major supplier as partner.

Table 4. 7 Top Management Commitments

\begin{tabular}{|c|c|c|c|}
\hline Questions & Valid & Frequenc & Percent \\
\hline $\begin{array}{l}\text { Top executives are actively involved in } \\
\text { Establishing and communicating }\end{array}$ & $\begin{array}{l}\text { Strongly } \\
\text { Disagree }\end{array}$ & 99 & 32.1 \\
\hline \multirow{5}{*}{$\begin{array}{l}\text { Establishing and communicating } \\
\text { organization vision, goals, and values } \\
\text { for quality program. }\end{array}$} & Disagree & 80 & 26.0 \\
\hline & Neutral & 42 & 13.6 \\
\hline & Agree & 73 & 23.7 \\
\hline & Strongly Agree & 14 & 4.5 \\
\hline & Total & 308 & 100.0 \\
\hline \multirow{6}{*}{$\begin{array}{l}\text { Top management views quality as } \\
\text { being more important than meeting } \\
\text { production schedules. }\end{array}$} & $\begin{array}{l}\text { Strongly } \\
\text { Disagree }\end{array}$ & 76 & 24.7 \\
\hline & Disagree & 116 & 37.7 \\
\hline & Neutral & 47 & 15.3 \\
\hline & Agree & 62 & 20.1 \\
\hline & Strongly Agree & 7 & 2.3 \\
\hline & Total & 308 & 100.0 \\
\hline \multirow{4}{*}{$\begin{array}{l}\text { Top management allocates adequate } \\
\text { resources towards effort to improve } \\
\text { quality. }\end{array}$} & $\begin{array}{l}\text { Strongly } \\
\text { Disagree }\end{array}$ & 87 & 28.2 \\
\hline & Disagree & 109 & 35.4 \\
\hline & Neutral & 62 & 20.1 \\
\hline & Agree & 46 & 14.9 \\
\hline
\end{tabular}




\begin{tabular}{|c|c|c|c|}
\hline & Strongly Agree & 4 & 1.3 \\
\hline & Total & 308 & 100.0 \\
\hline $\begin{array}{ll}\text { Top management strongly } & \text { encourages } \\
\text { Employee } \quad \text { involvement } & \text { in quality }\end{array}$ & $\begin{array}{l}\text { Strongly } \\
\text { Disagree }\end{array}$ & 116 & 37.7 \\
\hline \multirow{5}{*}{$\begin{array}{l}\text { Employee involvement in quality } \\
\text { management activities }\end{array}$} & Disagree & 78 & 25.3 \\
\hline & Neutral & 50 & 16.2 \\
\hline & Agree & 49 & 15.9 \\
\hline & Strongly Agree & 15 & 4.9 \\
\hline & Total & 308 & 100.0 \\
\hline \multirow{6}{*}{$\begin{array}{l}\text { All major department heads within our } \\
\text { company accept their responsibility for } \\
\text { quality. }\end{array}$} & $\begin{array}{l}\text { Strongly } \\
\text { Disagree }\end{array}$ & 125 & 40.6 \\
\hline & Disagree & 58 & 18.8 \\
\hline & Neutral & 47 & 15.3 \\
\hline & Agree & 67 & 21.8 \\
\hline & Strongly Agree & 11 & 3.6 \\
\hline & Total & 308 & 100.0 \\
\hline \multirow[t]{6}{*}{ Top management pursues long-term } & Strongly & 111 & 36.0 \\
\hline & Disagree & 93 & 30.2 \\
\hline & Neutral & 44 & 14.3 \\
\hline & Agree & 49 & 15.9 \\
\hline & Strongly Agree & 11 & 3.6 \\
\hline & Total & 308 & 100.0 \\
\hline
\end{tabular}

Source: Own Survey, 2018.

The table 4.7 above reveals that $32 \%$ of the respondents strongly disagree with the Top executives are actively involved in establishing and communicating the organization vision, goals, and values for quality program, $26 \%$ also disagree, $24 \%$ agree, $14 \%$ are uncertain with the statement the remaining $4 \%$ is strongly agree. From the analysis, the majority of 58\% disagrees with the statement.

Table 4.7 shows that $62 \%$ of the respondents are not agreeing with Top management views quality as being more important than meeting production schedules. But $22 \%$ agree with the statement which serves as Top management views quality as being more important than meeting production schedules and the remaining $16 \%$ been neutral. This implies that the Top management has not views quality as being more important than meeting production schedules.

The other point was about Top management allocates adequate resources towards effort to improve quality. From the above table 4.7 the respondents stated that $109(34.4 \%)$ of them are disagreeing, $87(28.2 \%)$ strongly disagree, $62(20.1 \%)$ neither Agree nor disagree, 46 (14.9\%) agree, the remaining 4 (1.3\%) strongly agree with the statement. From these result majorities or $196(63.6 \%)$ respondent answer the question disagree and above with the Top management allocates adequate resources towards effort to improve quality. This indicates that there is no allocation of adequate resources towards effort to improve quality at work place in company.

Again, when the respondents were asked to evaluate the extent to Top management strongly encourages employee involvement in quality management activities. Table 4.7 shows that the majority of respondents representing $63 \%$ are not Top management 
strongly encourages employee involvement in quality management activities whilst $21 \%$ agree with the statement the remaining $16 \%$ unsure of the statement. These suggest that Top management does not strongly encourage employee involvement in quality management activities in the company.

The other point was about the All major department heads within the company accept their responsibility for quality or not. From the above table 4.7 the respondents stated that 125 (40.6\%) of them are strongly disagreeing, $67(21.8 \%)$ agree, $58(18.8 \%)$ disagree, $47(15.3 \%)$ neither Agree nor disagree the remaining $11(3.6 \%)$ strongly agree with the statement. From the above result majority or $183(59.4 \%)$ respondent answer the question disagree and above with the major department heads within the company accept their responsibility for quality at work place. This indicates that there is no acceptance of major department head responsibility for quality at work place in company.

From the field survey, the results shows that $66 \%$ majority of the respondents believes that there is no Top management pursues long-term business success in the company and $20 \%$ of the respondents believes that there is Top management pursues long-term business success in the organization but $14 \%$ neither agree nor disagree as shown in table 4.7 above. This suggest that Top management is not pursues long-term business success in the company.

\subsection{Mean and Standard Deviation of Variables}

It explores and presents an overview of all variables used in the analysis. Descriptive statistics produced the mean and standard deviation for each variable for the study. Mean and standard deviation are used mostly in research studies and regarded as very satisfactory measures of variations. In brief, mean, SD is used to determine the extent of spread of the data. The summary statistics of all the variables in this study is presented as in the following table 4.8 shows that there are 308 observations for each variables, the mean and standard deviation values.

Table 4. 8 Mean and Standard deviation of Research variables

\begin{tabular}{|l|l|l|l|}
\hline Variables & N & Mean & Std. Deviation \\
\hline Continuous Improvement & 308 & 2.13 & 0.56 \\
\hline Customer Focus & 308 & 2.44 & 0.49 \\
\hline & & & \\
Process Management & 308 & 2.49 & 0.67 \\
\hline Supplier Quality Management & 308 & 2.27 & 0.63 \\
\hline Top Management Commitment & 308 & 2.30 & 0.69 \\
\hline Organizational Performance & 308 & 3.01 & 0.41 \\
\hline & & & \\
\hline
\end{tabular}

\section{Source: Own Survey, 2018.}

The above descriptive statistics clearly depicts the corresponding arithmetic mean and standard deviation of every construct totals (total of every individual categorical construct). Thus, continuous improvement total has a mean of 2.13 and a standard deviation of 0.56 , customer focus total has a mean of 2.44 and a standard deviation of 0.49 , process management total has a mean of 2.49 and a standard deviation of 0.67 , supplier quality management total has a mean of 2.27 and a standard deviation of 0.63 , 
top management commitment has a mean of 2.30 and a standard deviation of 0.69 . The results indicated the mean of the TQM dimensions ranged from 2.13 to 2.49. Process management has the highest mean 2.49 while continuous improvement has the lowest mean 2.13. Finally total quality management dimension in the company shows below the average cut-off point of three. The means of all variables in the study below the scale midpoint which is most respondents share similar opinions toward each variable in this study. This analysis of mean of categorical constructs showed that all constructs variables have a mean value less than the average standard. Accordingly, it implies that the low level of practicing TQM in the company. Also the SD is less than one; that is, the variations in respondent's opinions were small. The organizational performance mean value is 3.01 and standard deviation of 0.41 values indicates that respondents in the share company are answering at average standard in the study area or the same variations.

\section{SUMMARY OF FINDINGS, CONCLUSIONS AND}

\section{RECOMMENDATIONS}

This chapter presents the summary of the findings of the study, draws conclusions from the study and also makes recommendations for the study.

\subsection{Summary of Major Findings}

The study was carried out solely to identify the effect of total quality management on organizational performance. Accordingly, the major findings were derived from data discussions, analysis and interpretations as follows:-

\subsubsection{Continuous Improvement(CI)}

The finding showed that there is substantial positive relation between continuous improvement and organizational performance.

\subsubsection{Customer Focus(CF)}

There is positive relationship between customer focus with that of organizational performance.

\subsubsection{Process Management (PM)}

There is positive relationship between process management with that of organizational performance.

\subsubsection{Supplier Quality Management (SQM)}

There is positive relationship between Supplier Quality Management with that of organizational performance.

\subsubsection{Top Management Commitment (TMC)}

There is a positive significant relationship between Top Management Commitment with that of organizational performance.

\subsection{Conclusion}

The finding of the study indicates that organizational performance was affected by all total quality management practices namely; Continuous Improvement(CI), Customer Focus(CF), Process Management (PM), Supplier Quality Management (SQM), Top Management Commitment (TMC)

The finding of the study also indicates that, organizational performance mostly affected by Supplier Quality Management from the five total quality management practices.

The study also revealed that, organizational performance was lowly affected by process improvement from the five total quality management practices.

This publication is licensed under Creative Commons Attribution CC BY.

http://dx.doi.org/10.29322/IJSRP.11.09.2021.p11738

WWW.ijsrp.org 


\subsection{Recommendations}

In light of the summary of the findings and conclusions drawn above, the following major recommendations have been made.The company needed to engage suppliers of raw material. So the company would assist the firms to address the problem of raw material quality variations. Also by knowing Suppliers would be part and parcel of the value chain hence they end up knowing the exact quality requirements of the various stages of production and building a good relationship among suppliers.The company top management to show their commitment both in theory and practice. The vision, mission statement and company policies needed to be translated to action.

The company rely on their customers, so they must understand the current and future needs, and achieve their needs, and work to exceed their expectations. This is achieved through research and understand all the needs and expectations of the customer in terms of products, services and delivery date, price and reliability, and to link the goals established with the needs and expectations of the client, and follow the way of ensuring a balance between the needs and expectations of customers and other stakeholders (owners, employees, suppliers and the community), and inform all levels in the facility this needs and expectations, and measure customer satisfaction and act according to the results, customer relationship management to achieve the common interest.

The company should find new ways and techniques in producing better quality products, production are more competitive, as well as exceed customer expectations. And also designed to ensure efficient and effective utilization of the resources of the organization and to achieve a quality driven culture.

The company should grow a stronger culture that nurtures high-trust social relationship and respect for individuals, a shared sense of membership of the organization, and a belief that continuous improvement is for the common good. The company must identify the activities needed to achieve the desired result, and measure the inputs and outputs of the process, and to identify the communication channels of main activities of the business, and the risk assessment results and the potential impacts of operations on customers, suppliers and other stakeholders, define clearly the responsibilities and authorities of the of the management of main activities. The focus should be on how best design, manage and improve processes in order to fully satisfy, and generate increasing value for, customers and other stakeholders.

\subsection{Recommended Further Studies}

Although this research is directly focuses on distinguishing the relation between TQM dimensions (continuous improvement, customer focus, process management, supplier quality management, and top management commitment) and organizational performance, but several factors directly affected organizational performance because the study explained or accounted by the explanatory variables $41.9 \%$ of the variability of the dependent variable (organizational performance). Therefore, future researches could study the impact of TQM on organizational performance in wider scope by investigating the influences of other factors on performance. Another research focus should be carried out to study the implementation of TQM in the service and manufacturing sector to

provide a better understanding of TQM implementation.

\section{REFERENCE}

Ahire, S; Golhar, D; Waller, M. (1996). Development and Validation of TQM Implementation Constructs. Decision Sciences , 27 (1), 23-56.

Al-Damen, R. A. (2017). The impact of Total Quality Management on organizational performance Case of Jordan Oil Petroleum Company . International Journal of Business and Social Science , 8(1), 134-138.

Alkhafaji, A.F; Youssef, M.A.\& Sardessia, R. (1998). TQM strategic management and business process reengineering: the future challenge. International journal of Technology Management, 383-392.

Al-khalifa, K.N. and Aspinwall, E.M. (2000). The development of total quality management in Qatar. The TQM Magazine , 12(3), 194-204. 
Aysel, C.; Cengiz, D. and Makbule,S.Y. (2014). The effect of total quality management on the business performance:. 2nd GLOBAL CONFERENCE on BUSINESS, ECONOMICS, MANAGEMENT and TOURISM. 23(2015), pp. 1376-1382. Prague: Czech Republic.

Brah, S.A. and Tee ,S.S.L. (2002). Rlationship between TQM and performance of Singapore companies. International Journal of Quality \& Reliability Management , 19(4), 356-379.

Crosby, B. (1979). Quality is Free: the Art of making Quality certain. New York: McGraw-Hill.

Das, A. et al. (2006). TQM Implementation in the Thai Manufacturing Industry. International Journal of Innovation and Technology Management , 3(4), 361-377.

Deming, W. (1986). Out of the crisis quality; productivity and competitive position. Cambridge: Cambridge University.

Demirbag,M. and Koh, S.C.L. (2006). TQM and market orientations impact on SMEs performance. Industrial Management \& Data Systems , 106(8), 1206-1228.

Easton, G.S. and Jarrell, S.L. (1998). The effect of Total Quality Management on corporate performance: an emperical investigation. Journal of Business and Economic Studies , 71(2), 253-307.

Fotopoulos , c.; Kafetzopoulos .D. \& Psomas, E. (2009). Assesing the critical factors and and their impact on the effective implementation of a food safty management system. International journal of quality and reliability management , 894-910.

Gadenne, D. and Sharma, B. (2009). An investigation of the hard soft quality management factors of Australian SMEs and their association with firm performance. International Journal of Quality \& Reliability Management, 865-880.

Hendricks, K.B. and Singhal, V.R. (1997). Does Implementing effective TQM program Actually Improve Operating performance? Emperical evidence from firms have won quality awards . Management Science , 43(9), 1258-1274.

Huq, Z. and Stolen, J.D. (1998). Total quality management contrasts in manufacturing and service industrie. International Journal of Quality and Reliability Management, 15(2), 138-161.

Jaafreh, B.A. and Al-abedallat, Z.A. (2013). The effect of Quality Management Practices on Organizational Performance in Jordan:An emperical study. International Journal of Finance Research , 4(1).

Juran, J. (1974). Quality Control Hand book. London: McGraw-Hill .

Juran, J.M. and Gryna, F.M. (1988). Jurans Quality control Handbook. New York: McGraw-Hill Book co.

Kanji, G. (2002). Measuring business excellence. London: Rout lend.

Kanji, G.K. and Yui, H. (1997). Total quality culture. Total Quality Management , 8(6), 417-428.

Lee, G. (2004). Perception and Development of Total Quality Management in Small Manufacturers:An Exploratory Study in China. Journal of Small Business Management , 42(1), 102-115

Mugenda, O.M. \& Mugenda, A.G. (2003). Research methods; Qualitative and Quantitative approaches. Nairobi; Kenya: ACTs press.

Okland, J. (1993). Total quality management: the Route to improve performance. Oxford, UK: Butterworth-Heinemann Ltd.

Powell, T. (1995). Total quality management as a competitive advantage: A review and emperical study. Strategic Management Journal , 15-37.

This publication is licensed under Creative Commons Attribution CC BY. 
Prajogo, D.I. and Sohal, A.S. (2004). The meltidimensionality of TQM practices in determining quality and innovation performance. an emperical examination , 443-453.

Prajogo.D.I. and Brown. A. (2004). The Relationship between TQM practices and quality performance and the role of formal TQM programs: An Australian Emperical Study . The Quality Management Journal , 11(4), 31-42.

Sadikoglu ; Esin; and Oclay.H. (2014). The effect of Total Quality Management practice on performance and the Reasons of and Barriers to TQM practice in Turkey. Hind: Hindawi publishing corporation.

Salaheldin, S. (2009). Critical success factors for TQM implementation and their impact on performance of SMEs. International Journal of productivity and performance Management, 58(3), 215-237.

Samson, D. and Terziovski, M. (1999). The relationship between total quality management practice and operations performance. Journal of Operations Management, 393-409.

Saunders, M.; Lewis, p.; Thornhil, A. (2007). Research methods for business students. New Jersy, USA: Prentice Hall.

Shafiq, m.; Lasrado, F. \& Hafeez, K. (2017). The effect of TQM on organizational performance:emperical evidence from the textile sector of a developing country using SEM. Total Quality Management , 23-33.

Taguchi, G. (1999). Taguch's Robust Engineering: Worlds best practices for achieving Competitive Advantage in the new MIllenium. London: McGraw-Hill

Zabel,D. and Avery, C. (2002). The Quality Management Sourcebook:An international Guide to materials Resources. London: Routlege. 